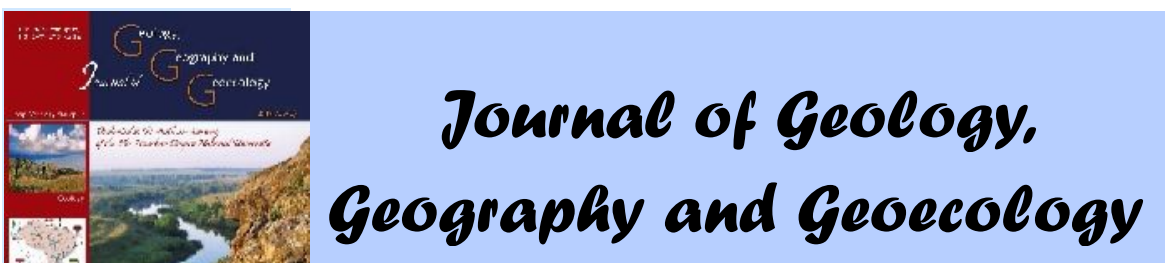

Journal home page: geology-dnu-dp.ua

I.O. Sadovenko, O.V. Inkin,

N.I. Dereviahina, Y.V. Hriplivec

Journ.Geol.Geograph.Geoecology, 27(2), 332-336

\title{
Analyzing the parameters influencing the efficiency of undereground coal gasification
}

\author{
I.O. Sadovenko, O.V. Inkin, N.I. Dereviahina, Yu.V. Hriplivec
}

National Mining University, Dnipro,Ukraine,e-mail: inkin@ua.fm

Received 20.07.2018;

Received in revised form 05.08.2018;

Accepted 04.10.2018

Abstract. Relying upon the theory and practice of Podzemgaz stations operation, the paper has analyzed the basic factors working on the efficiency of underground coal gasification; moreover, it has estimated their function in the formation of gas loss from underground gas generator. The determined factors have been divided into initial factors and controllable ones according to their process characteristics and degree of their influence of gasification process itself.The data confirm the dependence of the increased pressure upon the increased heat output. Moreover, high static pressure within gas generator prevents from rock roof caving and reaction channel filling up with molten rock. It has been substantiated that almost all disturbing factors have negative effect on gas calorifity whereas parameters of blast rate increase and static pressure growth in a gas generator have the most positive effect among the controlling factors. Aspects concerning the increase in loss of the produced gas that may reduce economic efficiency and environmental safety of underground coal gasification have been considered as well.

Keywords: filtration and crossflow processes, capacitive parameters, hydraulic fracturing, repression, relaxation, coal gasification

\section{ослідження п р метрів, що вплив ють н ефективність процесу підземної г зифік ції вугілля}

\author{
. . довенко, . . нкін, . . еревягін , . . рипливець \\ ерж вний "ціон льний гірничий університет", кр їн, e-mail: inkin@ua.fm
}

\begin{abstract}
нот ція. д ній роботі н б зі н уково-пр ктичного досвіду роботи ст нцій « ідземг з» досліджено основні ф ктори, що вплив ють н ефективність процесу підземної г зифік ції вугілля, т кож оцінюється їх роль у формув нні витоків г зу 3 підземного г зогенер тор . ст новлені ф ктори структуров ні по технологічним озн к м н вихідні т керов ні т ступені їх впливу н процес г зифік ції. ведені д ні підтверджують з лежність між підвищенням тиску і збільшенням теплотворення г зу. рім того, створення високого ст тичного тиску в г зогенер торі перешкодж є обв ленню його породної покрівлі і з повнення ре кційного к н лу розпл вленою породою. бгрунтов но, що пр ктично всі обурюючі ф ктори нег тивно вплив ють н теплотворну зд тність г зу, н йбільш позитивний вплив з керуючих ф кторів н д ють п р метри збільшення витр ти дуття т підвищення ст тичного тиску в г зовому генер торі. кож розглянуті спекти збільшення відходів виробленого г зу, що може знизити рент бельність т екологічну безпеку підземної г зифік ції вугілля.
\end{abstract}

лючові слов : фільтр ція $m$ процеси в покрівлі, ємнісні п р метри, гідророзрив, репресії, рел кс ція, г зифік ція вугілля.

Introduction. The necessity to make a technique of coal extraction, conversion, and use more ecologically feasible on the crucially new basis, while minimizing the environmental impact and reducing waste volume, is one of the topical problems to be solved by energy sector of Ukraine. Underground coal gasification (UCG) is the innovative solution to the problem. The process relies upon the transition of a mineral into a movable gas-condensate state within its occurrence by means of thermo- chemical and mass-exchange reactions. Gasification is fol-lowed by the loss of gas, being formed, into enclosing rocks which value is influenced by a number of factors. In this context, gas loss may achieve $30 \%$ affecting ecological compatibility and efficiency of UCG significantly. Thus, object of the paper is to study the parameters affecting the process of underground coal gasification as well as gas loss into roof rocks of underground gas generator. 
Statement of basic material of the research. Relying upon domestic and the world practices, as well as scientific research (Korolev, 1962, Yefremochkin, 1960, Yudin, 1958, Saik, 2018), following basic factors, affecting the efficiency of underground coal gasification, can be singled out: 1) mining and geological environment of the deposit occurrence; 2) amount of water, involved into the gasification process; 3) mineral composition of coal; 4) characteristics of blast delivered to the gas generator; and 5) arrangement of wells. The factors may be divided into controllable (those which can be varied during UCG process), i.e. blast characteristics, and arrangement of wells; and initial factors (which cannot be varied), i.e. mineral composition, and coal seam thickness.

Coal seam thickness, its depth as well as tectonic disturbance of enclosing rocks are among the mining and geological conditions affecting UCG process. Increased seam thickness results in the decreased heat loss in the environment, decreased specific water inflow, and ultimately, in the increased gas heat as well as gasification process efficiency. However, specific gas output lowers due to the decreased seam mining as for its thickness. Thus, according to operation data of gas generators \#\#5, 5a-b, and 6 of Yuzhno-Abinskaia station of Podzemgaz (Nusinov, 1963), gas heat output, obtained within Vnutrenni $V$ seam with 9 m thickness, is $1-1.5 \mathrm{MJ} / \mathrm{m}^{3}$ higher to compare with $V n u$ trenni $V$ seam with $2.2 \mathrm{~m}$ thickness. In this context, specific gas output is less by $1 \mathrm{~m}^{3} / \mathrm{kg}$ and gasification efficiency of thicker seam is $10-15 \%$ higher.

a

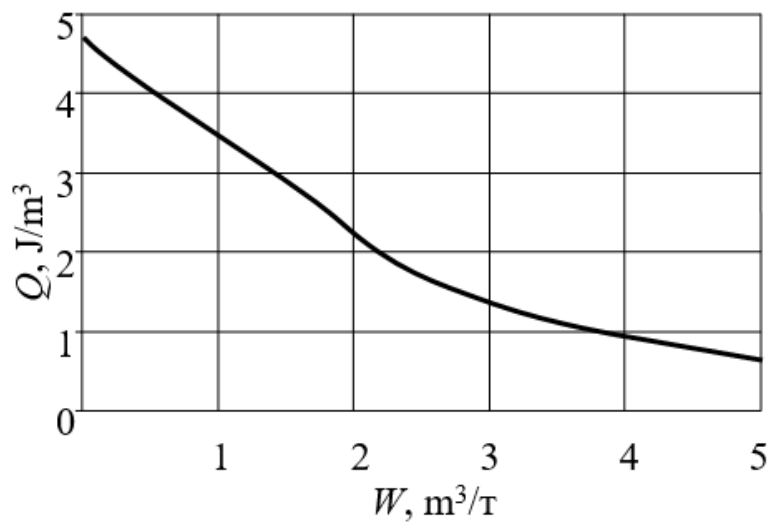

Coal seam shallowness results in gas loss through overlying rocks; in turn, significant coal seam depth results in sharp efficiency decrease. Availability of faults, tectonic disturbances, and complicated seam hypsometry troubles the development of a reaction channel as well as control over a combustion source. Less than $100 \mathrm{~m}$ depth of a coal seam occurring within undisturbed rocks is optimum for its mining by means of UCG technique making gasification process more stable (Yefremochkin, 1960).

In the process of UCG, water balance is formed of natural coal humidity, inflows of water to a gas generator, water, containing in the blast, and water, being formed in the process of carbon, hydrogen, and methane combustion as well as $C O$ conversion. Low water within the coal as well as nonavailability of water inflows may results in moisture lack which will decelerate gasification process; among other things that gives rise to the decreased $C O$ formation during reduction reactions. Much water decelerates coal seam degassing, and reduces heat content of gas, being generated, due to its increased water ratio (Fig. 1). Hence, the amount of water, involved in UCG process, should be controlled strictly depending upon specific conditions.

The main procedures to control amount of water, participating in UCG process, are: preliminary dewatering of a deposit by means of drain wells; increased pressure of the blast to displace moisture from the gas generator; increased oxygen content within the blast; and increased air to be supplied. b

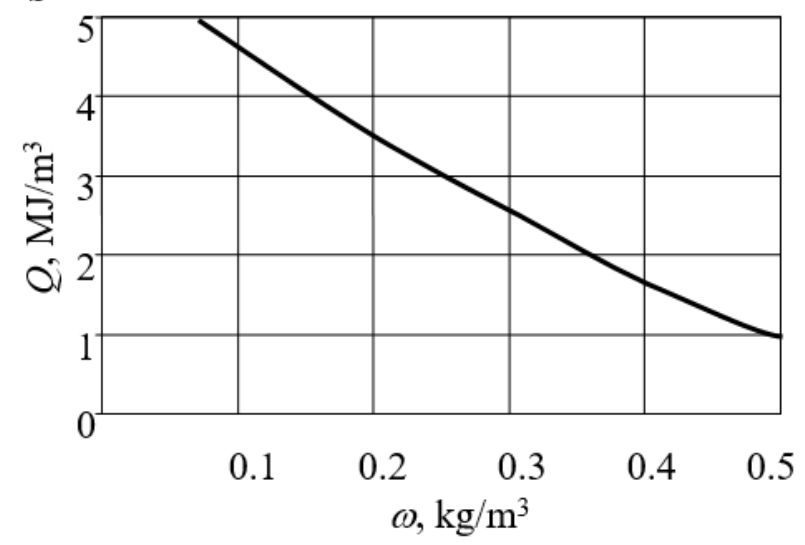

Fig. 1 Dependence of gas heat output $(Q)$ upon: - specific water inflow to the seam $(W)$; and b - gas water content $(\omega)$

Changes in characteristics of blast, delivered to the gas generator as well as chemical content of the blast, delivery rate, and delivery pressure are the important factors effecting gasification procedure (Arinenkov, 1960, Inkin, 2018). Analysis of the results of coal seams gasification shows that blast oxygenation increases temperature within combustion area; delocalizes it; and intensifies heat output of the gas, being generated. If oxygen content of the blast to be delivered is two times higher than atmospheric one, then the content of $C O$ and $\mathrm{H}_{2}$ experiences 1.5 to 2 times increase. Water va- 
pour with $0.15-0.2 \mathrm{~kg} / \mathrm{m}^{3}$ content added to air blast (within the drained deposits) intensifies reduction reactions increasing , $\mathrm{H}_{2}$, and $\mathrm{CH}_{4}$ output. Combined use of oxygen and water vapour (i.e. vapouroxygen blast) is more efficient. A Table demonstrates the influence of blast content on the heat output of the generated gases in the context of different UCG stations.

Experiments, concerning the effect of blast intensity on the gasification process were carried out within gas generator \#1 of Yuzhno-Abinskaia station of Podzemgaz during its different operation periods. To begin with, blast consumption was increased from 1000 to $6500 \mathrm{~m}^{3}$ per hour; then, it was decreased gradually from 6500 down to $1000 \mathrm{~m}^{3}$ per hour. Fig. 2 explains changes in the content and gas heat output in terms of various consumption of blast delivered for gasification.

Table. Influence of the blast chemical composition on the gas heat output

\begin{tabular}{|l|l|c|}
\hline \multicolumn{1}{|c|}{ Blast type } & \multicolumn{1}{|c|}{ Station } & Gas heat output, $\mathrm{J} / \mathrm{m}^{3}$ \\
\hline \multirow{3}{*}{ Air blast } & Lisichanskaia & 3.1 \\
\cline { 2 - 3 } & Podmoskovnaia & 3.6 \\
\cline { 2 - 3 } & Yuzhno-Abinskaia & 4.6 \\
\hline \multirow{2}{*}{ Oxygen blast } & Lisichanskaia & 5.3 \\
\cline { 2 - 3 } & Podmoskovnaia & 7.3 \\
\hline Vapour-air blast & Yuzhno-Abinskaia & 6.3 \\
\hline Vapour-oxygen blast & Podmoskovnaia & 6.8 \\
\hline
\end{tabular}

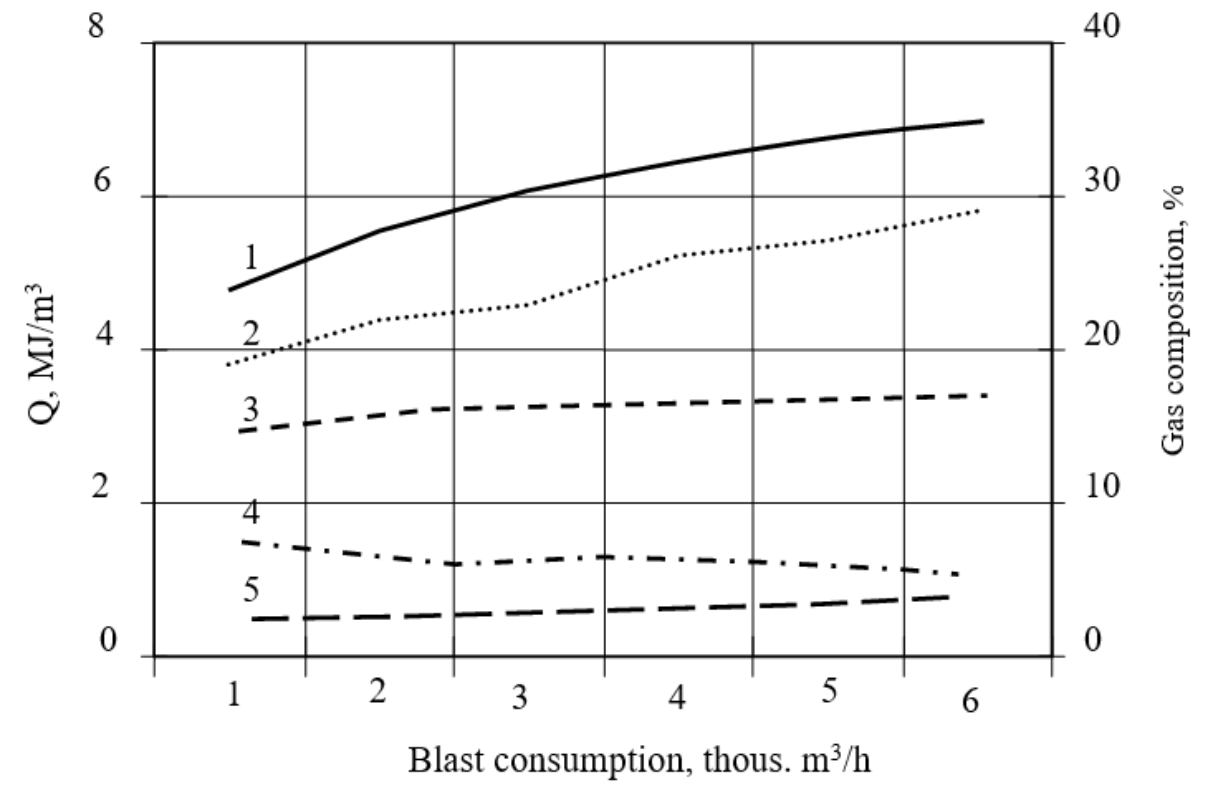

Fig. 2. Changes in gas heat output $Q(1)$ and its composition

The graph demonstrates that gas heat output increases depending upon the increase in the blast consumption. Moreover, the increase in heat value depends on carbon monoxide mainly. Carbon dioxide content within the gas reduces moderately while blast intensity increasing; at the same time, content of other components remains constant being more or less independent of the blast consumption.

Experiments have determined (Kulish, 1958) that in addition to the blast intensity, interrupted blast to a reaction channel is one of the factors intensifying heating value of gas as well as the efficiency of UCG station. Fig. 3 represents a graph of changes in gas composition in the context of Gor-
(2), $\quad{ }_{2}(3), \quad{ }_{2}(4), \quad{ }_{4}(5)$ in terms of various blast types

lovka Podzemgaz station. When gasification channel operated with the use of air blast (section A), $\mathrm{H}_{2}$ $+\mathrm{CH}_{4}$ content within the gas was $15-18 \%$ in the context of $4.8 \mathrm{MJ} / \mathrm{m}^{3}$ average heating value. After blast was interrupted to the gasification channel, intensive increase in $\mathrm{H}_{2}+\mathrm{CH}_{4}$ content started; the increase continued during the whole blastless period (section B). Then, when blast was restarted, composition of the gas, being generated, varied sharply. After 80 minutes it came up to the level when the channel operated with the use of air blast, i.e. ${ }_{2}+{ }_{4} \approx 15-18 \%$ (section C). During blastless period, the peak ${ }_{2}+{ }_{4}$ content was $58 \%$, and heat output was up to $11 \mathrm{~J} / \mathrm{m}^{3}$. 


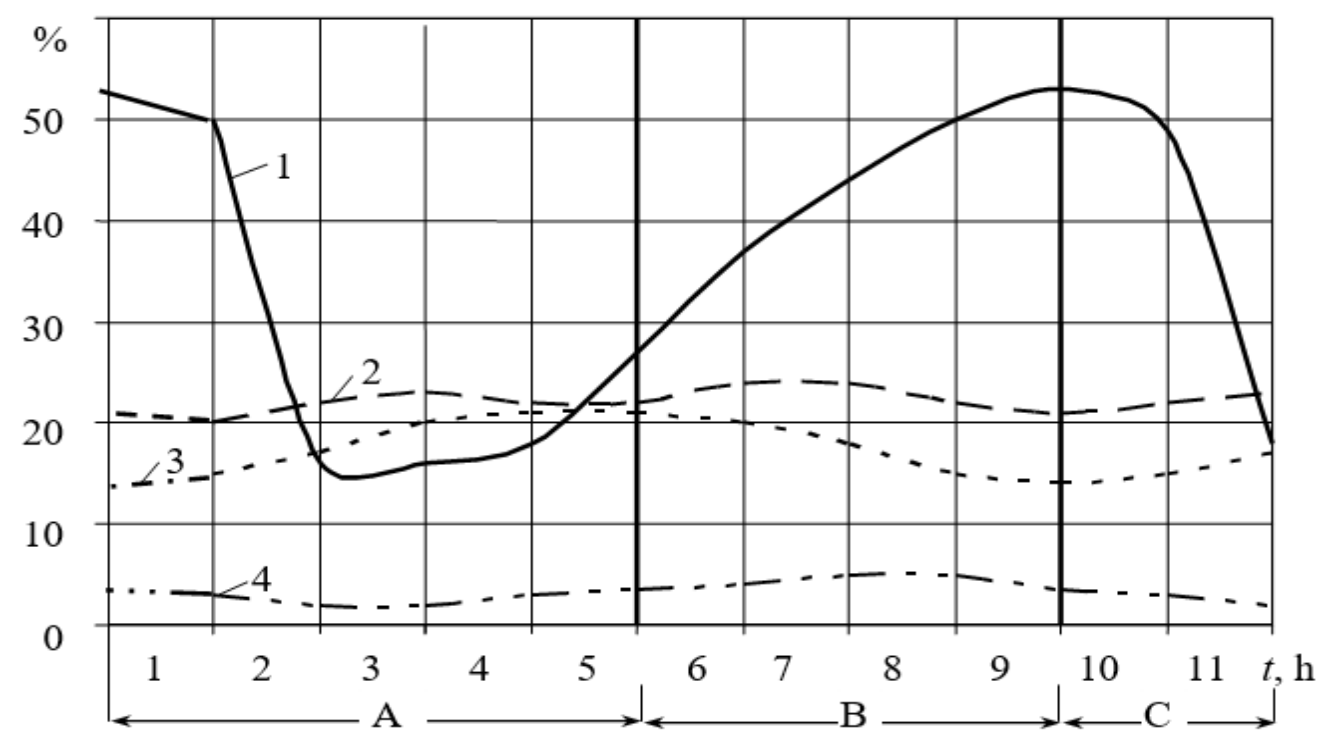

Fig. 3. Changes in the concentration of gas components $\left(1-_{2} ; 2-\quad 2 ; 3-\quad ; 4-\quad{ }_{4}\right)$ during blast and blastless periods of underground gas generator operation

Ash washing off coal surface, decreased aerodynamic drag factor, and increased coal loosening are the advantages of pulsating blast delivery. Use of the technique intensifies a process of gas release, and reduces the influence of negative factors arising with uniform blast.

Effect of static pressure within gas generator on gas heat output and loss value was analyzed at Podmoskovnaia station of Podzemgaz during 1954-
1956 (Garkusha, 1964). During the period, static pressure varied significantly; averaged data can help estimate its change influence (Fig. 4). As it is seen in the graphs, increased pressure results in the increased heat output as well as in the increased gas loss. Average $10^{4} \mathrm{~Pa}$ pressure increase results in $0.25 \mathrm{MJ} / \mathrm{m}^{3}$ gas heat output increase and in $5 \%$ gas loss increase.

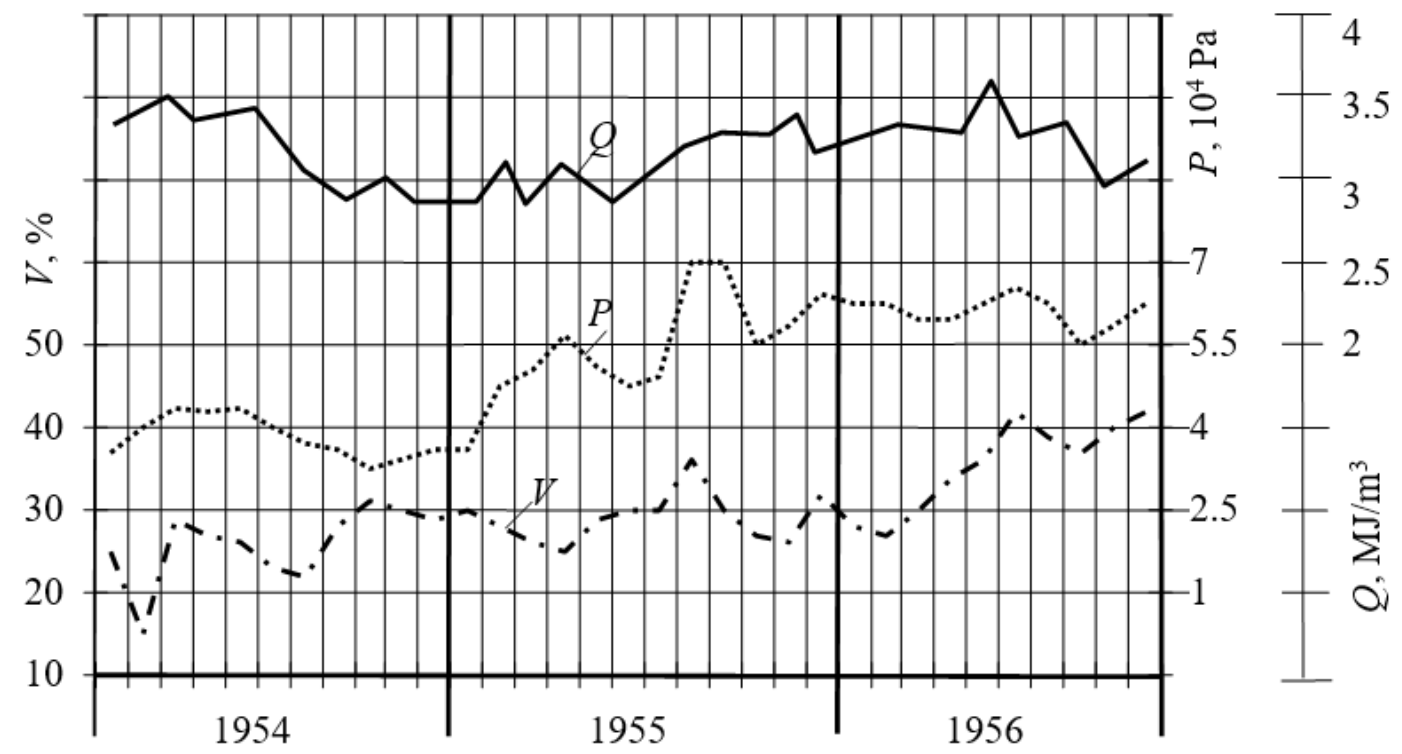

Fig. 4. Changes in static pressure ( ), heat output $(Q)$, and gas loss $(V)$ in Podmoskovnaia station of Podzemgaz

Fig. 5 shows changes in gas humidity depending upon static pressure. Increase of static pressure results in certain forcing out of formation water owing to which moisture content of the gas reduces. The data confirm the dependence of the increased pressure upon the increased heat output. Moreover, high static pressure within gas generator prevents from rock roof caving and reaction channel filling up with molten rock. 


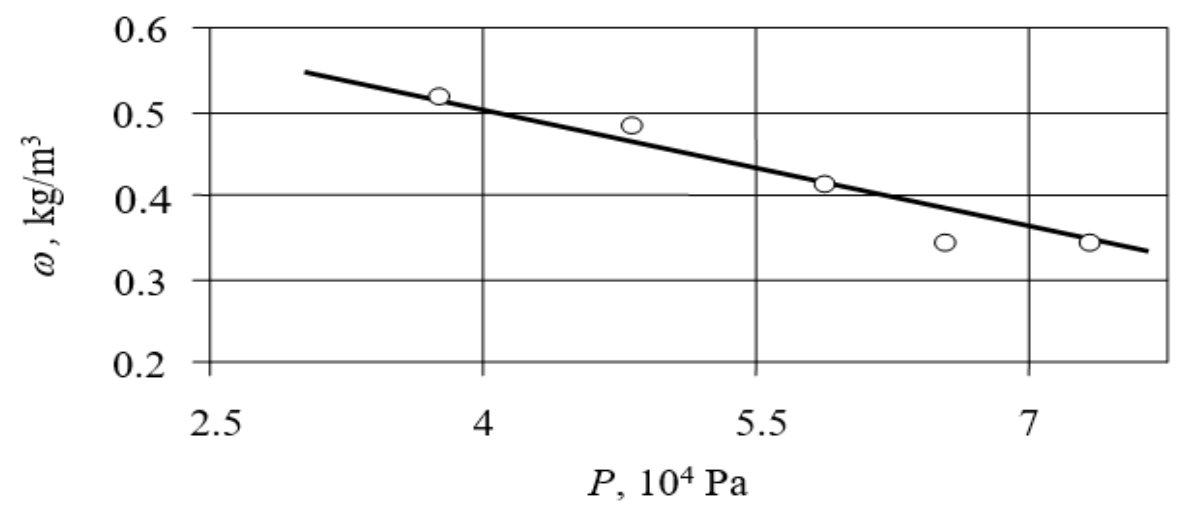

Fig. 5 Dependence of gas humidity $(\omega)$ upon static pressure ( )

Conclusions. Thestudies concerningthe factors, working upon the efficiency of underground coal gasification, have shown that perturbing factors are not equal to controlling ones in terms of their degree of influence. All the perturbing factors with the exception of a coal seam thickness have an adverse effect on gas heating power; in turn, blast characteristics are the most favourable ones among controlling factors. Hence, increased blast consumption and increased static pressure within a gas generator are the most active controllable factors working on the efficiency of UCG process. Conversely, that results in the increased gas loss which may decrease both profitability and environmental safety of UCG.

\section{References}

Arinenkov D.M., Markman L.M., 1960. Podzemnaya gazifikatsiya uglya [Underground coal gasification]. Donbass: Knizhnoye izdatel'stvo Stalino. 94. (in Russian).

Garkusha I. S. 1964. Podzemnaya gazifikatsiya uglya [Underground coal gasification]. Trudy instituta i proizvodstvennyy opyt. Moskva. Nedra. №12, 36. (in Russian).

Inkin O., Dereviahina N., 2018. Study of the migration processes in the roof of an underground gasgenerator. Dniprop. Univer. bulletin, Geology, geography.26 (1), $64-70$.

KorolevI.V., 1962. Zavisimost' protsessaPGUotgeologicheskikhigidrogeologicheskikhusloviynakamennougol'nykhmestorozhdeniyakh[Dependence of the UCG process on geological and hydrogeological conditions at coal deposits]. VNIIPodzemgaz, nauchnyyetrudy. Podzemnaya- gazifikatsiyaugley. Moskva. Gosgortekhizdat. № 8, 64 - 70. (inRussian).

Kulish Ye. D., 1958. Podzemnaya gazifikatsiya podmoskovnykh burykh ugley [Underground gasification of Moscow brown coal]. Moskva. Ugletekhizdat. 36. (in Russian).

Nusinov G.O., Brushteyn N.Z., Kulakova M.A., Dotsenko P.N., 1963. Podzemnaya gazifikatsiya na obvodnennykh ploshchadyakh ugol'nogo plasta [Underground gasification on the water-filled areas of a coal seam]. VNIIPodzemgaz, nauchnyyetrudy. Podzemnayagazifikatsiyaugley. Moskva. Gosgortekhizdat. № 9,85 - 88. (in Russian).

Saik, ., Petlovanyi, ., Lozynskyi, V., Sai, K. and Merzlikin, A., 2018. Innovative Approach to the Integrated Use of Energy Resources of Underground Coal Gasification. Solid State Phenomena, 277, 221-231.

Sotskov, V.O., Demchenko, Yu., Salli, S.V. \&DereviahinaN.I., 2017. Optimization of parameters of overworked mining gallery support while carrying out long-wall face workings. Naukovyi Visnyk Natsionalnoho Hirnychoho Universytetu. №6, $34-40$.

YefremochkinN.V.,

1960.Osobennostirezhimapodzemnykhvodvuslovi yakhgazifikatsiiugleynaShatskommestorozhdenii[Features of the groundwater regime in terms of coal gasification at the Shatskoye field]. VNIIPodzemgaz, nauchnyye trudy. Podzemnaya gazifikatsiya ugley. Moskva. Gosgortekhizdat. № 3, 29 - 33. (in Russian).

Yudin I.D., Grigor'yev V.V., 1958. Podzemnaya gazifikatsiya uglya v Kuzbasse[Underground gasification of coal in Kuzbass]. Moskva. Ugletekhizdat, 28. (in Russian). 